\title{
Sugar Press Mud as a Proposed Futuristic Aqua-fertilizer - Multi-Elemental Quantitative Characterization by Inductively Coupled Plasma Optical Emission Spectrometry (ICP-OES)
}

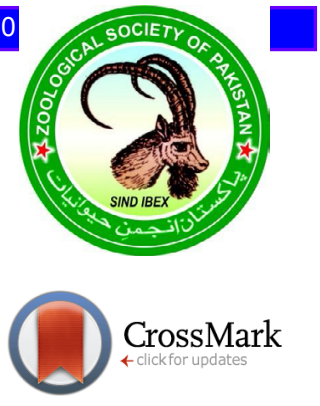

\author{
Kashifa Naghma Waheed ${ }^{1,2, *}$, Zaid Mehmood $^{2}$ and Sikender Hayat ${ }^{1}$ \\ ${ }^{1}$ Fisheries Research and Training Institute, Department of Fisheries, Lahore \\ ${ }^{2}$ Institute of Chemistry, University of the Punjab, Lahore
}

\begin{abstract}
A B S T R A C T
In this research, characterization of press mud, a by-product of sugar industry in respect of its multielemental availability was taken into consideration to check its feasibility as an aqua-fertilizer. Eighteen elements including essential macro-elements, essential trace elements and non-essential toxic elements were quantitatively analyzed in sugar press mud by ICP-OES following protocols of AOAC from five randomly selected sugar mills situated in South Punjab, Pakistan. It was observed that the samples contained potential amounts of essential elements, while the toxic elements were present in low quantities. The results were statistically analyzed and compared for their significance and showed significantly higher quantities of $\mathrm{Ca}, \mathrm{Na}, \mathrm{K}, \mathrm{Fe}, \mathrm{Mg}$ followed by relatively lower quantities of $\mathrm{Al}, \mathrm{Mn}$ and low quantities of $\mathrm{Zn}, \mathrm{Co}, \mathrm{Ba}, \mathrm{Li}, \mathrm{Pb}, \mathrm{Cu}, \mathrm{Sr}, \mathrm{Ni}, \mathrm{Cr}, \mathrm{La}$ and $\mathrm{Cd}$. It was concluded that this naturally fortified by-product of sugar industry can be beneficially employed as a valuable futuristic fertilizer in aquaculture processes.
\end{abstract}

\begin{tabular}{l} 
Article Information \\
Received 02 August 2016 \\
Revised 13 January 2018 \\
Accepted 28 March 2018 \\
Available online 25 May 2018 \\
Authors' Contribution \\
KNW conceived the project, collected \\
the samples, planned and performed \\
the research, statistically analyzed the \\
data and composed the research paper. \\
ZM and SH guided, facilitated and \\
supervised the research. \\
\hline Key words \\
Essential macro-elements, Essential \\
trace elements, ICP-OES, Non- \\
essential toxic elements, Sugar press \\
mud.
\end{tabular}

\section{INTRODUCTION}

$\mathrm{P}$ akistan is the $8^{\text {th }}$ largest sugar producer country in the world, at $6^{\text {th }}$ position in terms of sugarcane production and at $7^{\text {th }}$ position in terms of export of white sugar among the Global sugar production countries on the basis of evaluation conducted in 2014 by Pakistan Sugar Mills Association. The total area under sugarcane cultivation comprises of 1.172 hectares/tonnes producing 67.428 hectares/tonnes of sugarcane. The sugar production remained at 5.588 hectares/tonnes out of Sugarcane crushed (a) 56.460 hectares/tones and the cane utilization remained at $84 \%$. In present scenario, the Sugar Industry is the second largest agro-based industry in Pakistan following Textile Industry. There are a total of 82 Sugar Mills in this country in the vicinity of sugarcane cultivation areas; out of which 45 (44 in working conditions) are situated in the province of Punjab covering 55\% of the total Mills and $60 \%$ of the total cane sugar production of the country. The South Punjab holds 13 number of Sugar Mills among a total of 44 (PSMA, 2014).

During filtration of sugarcane juice, certain byproducts including bagasse, press mud and molasses are

\footnotetext{
Corresponding author: kashifanw@gmail.com 0030-9923/2018/0004-1329 \$ 9.00/0

Copyright 2018 Zoological Society of Pakistan
}

also released. Out of these, Sugar press mud also known under the names of filter cake and mud cake is an important but neglected by-product which is produced @ 3-4\% of the total fresh sugarcane input on the annual basis. This compressed by-product obtained from sugar mills during the sugar manufacturing process, is reported to be a soft, spongy, amorphous, dark brownish material containing almost $75-80 \%$ moisture, high organic carbon contents along with appreciable amounts of macronutrients (N, P, $\mathrm{K}, \mathrm{Ca}, \mathrm{Mg}, \mathrm{S}$ ) and micronutrients / trace elements, also (Kale and Shinde, 1986; Solaimalal et al., 2001; Rashi et al., 2005). There is still no market of press mud in Pakistan; it is merely wasted resulting in heaps and heaps of this agro-industrial waste being piled up in the grounds adjacent outside the Mills. United Nations Industrial Development Organization (UNIDO) also reported that nearly 1.2 million tons of press mud produced during 2009 in Pakistan was mostly discarded by the sugar industries (Naseem, 2009). However, this by-product can be utilized primarily not only as a source of energy but also as a source of nutrients, soil ameliorants and fertilizer, too. Its re-use can be very useful to the farming and milling sectors as well as supporting other industries (Qureshi et al., 2001). It is indeed mutually beneficial to the horticulture and agricultural crops from point of view of its richness in various micronutrients (Partha and Krishnan, 2000; Saravane et al., 2005; Partha and Sivasubramanian, 2006). 
There are reports of use of press mud as fuel/energy source in brick production Kilns in Pakistan but never utilized as a fertilizer in freshwater aquaculture/fish culture systems. This preliminary study has been taken up for the first time to investigate the Multi-Elemental analysis including essential and non-essential metal profile determination of this neglected valuable by-product of sugar industry to check its feasibility as a futuristic fertilizer in fish culture system since there is very less and limited information regarding the amount of elements present in sugar press mud from all over the world. This will be a great contribution and support towards the economic strengthening of the region by using this waste for reducing, recycling and reusing purposes through 3R's formula.

\section{MATERIALS AND METHODS}

\section{Study area, sampling stations and sample collection}

The Sugar press mud (SPM) samples were fetched from randomly selected five Sugar Mills namely The Thal Industries (unit 1) Corporation Ltd. (Layyah), Indus Sugar Mills Ltd. (Rajanpur), Fatimah Sugar Mil (Muzaffargarh), Etihad Sugar Mills Ltd. (Karamabad, Rahim Yar Khan) and Ashraf Sugar Industries (Ashrafabad, Bahawalpur). The samples were collected in large sterilized polythene bags directly from the outlets pipes, coming from press mud wheelers inside the premises of Mills, in order to avoid any contamination and then were properly labeled. The safety hazards associated with the samples collection were taken into consideration. These samples were then transported to the FR\&TI, Lahore. Each individual sample was mixed thoroughly, placed in separate labeled trays and allowed to air dried completely. The representative sub-samples (of each Sugar Mill) were then randomly collected in triplicate (03 in number) from the air dried bulk of each particular Mill; homogenized by pestle mortar and preserved in small tightly sealed properly labeled polythene bags till the initiation of digestion for way up to multi-elemental analysis of theses samples.

\section{Machinery and equipment}

The machinery and equipment used in this research included Inductively coupled plasma-optical emission spectrometer (Brand: PerkinElmer, Model: Optima 7000 DV, Made: USA) with all accessories, environment friendly ductless Fuming hood, digital heavy duty Hot plate with controllable variable temperature and capacity $1000^{\circ} \mathrm{C}$ (Made: PCSIR, Lahore), Utra purification system (Brand: Millipore). All laboratory formalities were considered and precautionary measures needed to be taken into account were implemented during the entire experimental work like sampling technique, acid digestion processes, acid fumes/toxics handling, gas cylinders hazards and plasma precautions, etc. The Instrumental operating conditions applied during the entire analysis are evident from Supplementary Table I and the ICPOES Laboratory environmental conditions maintained during the present research were as follows: Temperature, $18 \pm 2^{\circ} \mathrm{C}$; relative humidity, $45 \pm 5 \%$; cleanliness, dust free; location, vibration free; atmosphere, fumes free. The limits of detection of the method and instruments were developed and optimized as expressed in Supplementary Table II. The elemental parameters including applied selected wavelengths $(\mathrm{nm})$, working standards range, correction coefficient of calibration (obtained through calibration curves of standards) and resulting quality control checks (\% recovery) through spiking can be visualized from Supplementary Table III.

\section{Apparatus/glassware}

The glassware used for the preparation of chemicals, reagents, stock solutions, working standards and sugar press mud (SPM) samples comprised of volumetric flasks, beakers and pipettes got calibrated from PCSIR, Internationally Accreditated Laboratories, Lahore, Pakistan.

\section{Reagents}

All chemicals/reagents used were of Analytical reagent grade, Merck brand and required strengths prepared with double de-ionized (DDI) ultrapure water obtained from Millipore ultra-purification system. The working standard solutions were prepared from the provided strengths combinations as shown in Supplementary Table III by further and serial dilutions as required by the method within the ranges observed for the detection of the required elements.

\section{Technical section reference}

The SPM samples digestion and then selected metals determination therein were obtained following AOAC official methods of analysis, 990.08 for Metals in solid waste, Section 9.2.39.

\section{Analytical procedure for wet sample digestion}

The analytical procedure adopted for digestion of all SPM samples is briefly described as under. Initially, $2.0 \pm 0.005 \mathrm{~g}$ of each of preserved dried homogenized press mud sample was weighed, transferred to a $100 \mathrm{~mL}$ beaker and then $15 \mathrm{~mL}$ conc. $\mathrm{HNO}_{3}$ was added to it. The beaker was covered with a watch glass and heated at $95^{\circ} \mathrm{C}$ 
for $30 \mathrm{~min}$. The precaution was taken to prevent it from drying by putting 1-2 mL DDI water as and when required. Afterwards, $2 \mathrm{~mL}$ water $+10 \mathrm{~mL} 30 \% \mathrm{H}_{2} \mathrm{O}_{2}$ were added to it and heated slowly till the solution became transparent. This was cooled the final volume made upto $100 \mathrm{~mL}$ with DDI ultrapure water, filtered through $0.45 \mu \mathrm{m}$ filter paper for removal of any particulate material, preserved in the refrigerator at $4^{\circ} \mathrm{C}$ in $125 \mathrm{~mL}$ properly labelled tightly stoppered glass storage bottles.

\section{ICP-OES determination}

During the multi-elemental analysis in Sugar Press Mud samples by ICP-OES instrument, the quality assurance was taken into consideration through initializing quality control checks (QCS) i.e., preparing spike samples by spiking the SPM sample with known amount of element and then finding its \% recovery after analyzing on the same instrument during analysis of all other samples for the same metal. These results have been recorded in Supplementary Table III. The SPM samples were prepared and analyzed in triplicate for all the metals, moreover, each metal was also subjected to instrumental triplicate element analysis for which no variation in results were observed confirming the accuracy of the sample preparation, accurate calibration procedures and validity of applied method. The WinLab32 software operating system under Microsoft Windows operating systems was used as a tool.

The following relationship was used for calculating final concentration of the elements under consideration:

$$
\mathrm{FCE}=(\mathrm{EC}-\mathrm{B}) \times \mathrm{DF}
$$

Where, $\mathrm{EC}$ is element concentration obtained from the ICP-OES instrument, B is concentration of the laboratory reagent blank (LRB), DF is dilution factor (equal to 50 since $2 \mathrm{~g}$ was diluted to $100 \mathrm{~mL}$ ) and FCE is final concentration of element in the SPM sample obtained from calculating all the above

\section{Statistical analysis}

The reported results obtained through research were subjected to statistical analysis following Steel et al. 1996. The results description involved following five steps. 1) Bar comparison graphs of mean \pm SEM values of triplicate sample analysis having standard error bars for all elements of five sites (on Microsoft Excel), 2) Descriptive statistics including minimum, maximum, median, arithmetic means, standard error, standard deviations, variance and 95\% confidence interval values (SPSS 21 package programme), 3) One way Analysis of Variance (ANOVA) to find out the level of significance (SPSS 21 package programme), 4) Correlation analysis considered significant at $\mathrm{P}<0.05$,
$\mathrm{P}<0.01, \mathrm{P}<0.001$ (SPSS 21 package programme) and 5) Summary of elements concentration in press mud from different locations of the world (literature survey).

\section{RESULTS}

The individual test results of multi-elemental concentrations $\left(\mu \mathrm{gg}^{-1} \pm \mathrm{SEM}\right.$ dry weight) found in Press Mud samples of various Sugar Mills located in South Punjab, Pakistan are shown in Figures 1, 2 and 3. The results showed that all the eighteen elements under consideration were mostly and positively found in all the samples with the exception of the few non-essential metals. Among all the studied essential elements, $\mathrm{Ca}$ had the overall highest concentration in all the press mud samples collected from the five Sugar Mills followed by the rest of the elements i.e. $\mathrm{Na}, \mathrm{K}, \mathrm{Fe}, \mathrm{Mg}, \mathrm{Al}, \mathrm{Mn}, \mathrm{Zn}, \mathrm{Pb}, \mathrm{Sr}, \mathrm{Ba}, \mathrm{Cu}, \mathrm{Co}, \mathrm{Ni}, \mathrm{Li}, \mathrm{Cr}$, $\mathrm{La}$ and $\mathrm{Cd}$ in descending order, respectively. The results of compiled descriptive statistics of above mentioned elements; including the minimum, maximum, mean, median, standard error, standard deviation, variance and 95\% confidence interval of all the samples are presented in Supplementary Table IV. These metals were basically divided into three broad categories for ease in evaluation of the results i.e., essential macro-elements (including $\mathrm{Ca}, \mathrm{K}, \mathrm{Mg}, \mathrm{Na}$ ), essential trace elements (including $\mathrm{Co}$, $\mathrm{Cr}, \mathrm{Cu}, \mathrm{Fe}, \mathrm{Mn}, \mathrm{Ni}, \mathrm{Zn}$ ) and non-essential toxic elements (including Al, Ba, Cd, La, Li, Pb, Sr). Our study showed that the contents of afore-mentioned three categories were different with respect to each other.

\section{Essential macro-elements}

The elements, $\mathrm{Ca}, \mathrm{K}, \mathrm{Mg}$, Na required in large amounts, have essential and versatile role in fish growth, metabolic requirements and biological functions. The comparison of average/mean concentration with standard error bars of these essential macro-elements in SPM samples can be better understood from Figure 1. It is revealed that the $\mathrm{Ca}$ mean concentration $\left(18005.00 \pm 430.47 \mu \mathrm{g} \mathrm{g}^{-1}\right)$ was found highest in Press Mud obtained from The Thal Industries (Unit-I) Corporation Ltd., Layyah while lowest (8040.00 $\pm 195.13 \mu \mathrm{g} \mathrm{g}^{-1}$ ) was observed in Indus Sugar Mills Ltd., Rajanpur in comparison with all the other Sugar Mills. Since Calcium is a key component in the maintenance of cell structure and fulfils important physiological roles as cofactor for many enzymes, important component of the blood clotting mechanism, an active role of intracellular signal, etc. Its deficiency leads to stunted growth, poor quality bones/teeth and bone malformation (Bucher et al., 1996; COMA, 1998). 


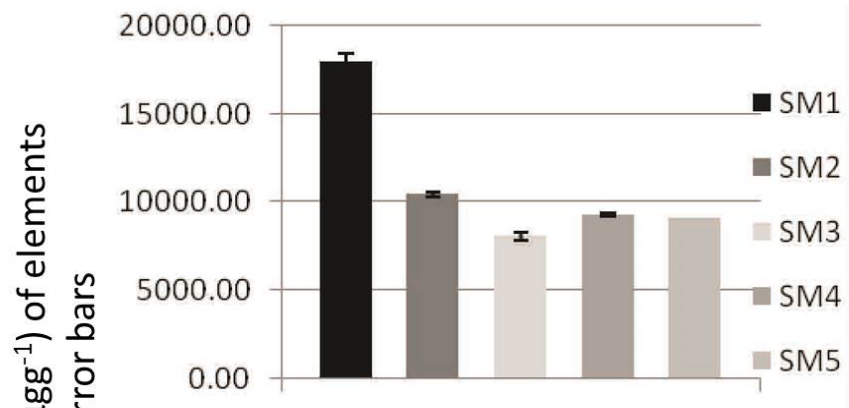

$\mathrm{Ca}$

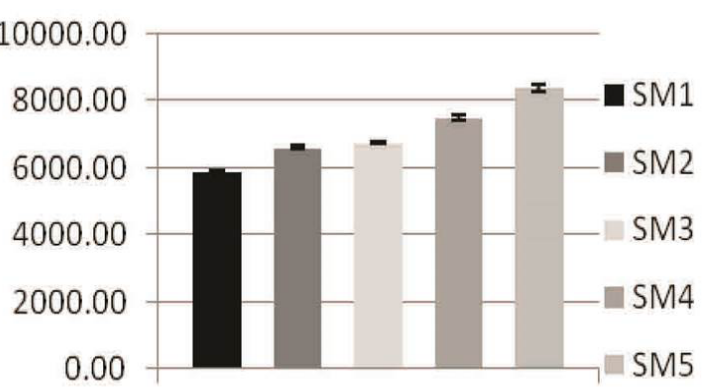

$\mathrm{Na}$

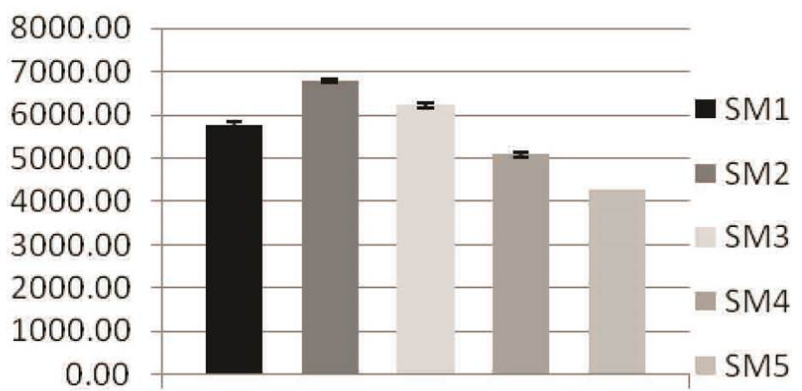

K

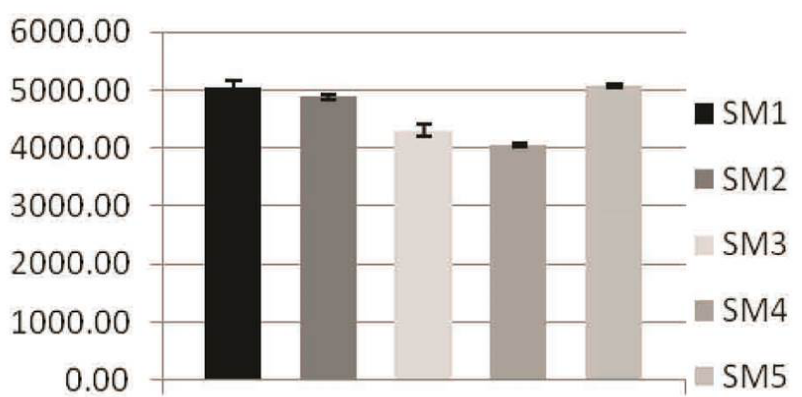

$\mathrm{Mg}$

Fig. 1. Essential macro-mineral elements in press mud samples from various Sugar Mills in South Punjab, Pakistan.

The mean concentration of $\mathrm{K}$ remained at highest $\left(6796.33 \pm 53.36 \mu \mathrm{g} \mathrm{g}^{-1}\right)$ in Press Mud of Fatima Sugar Mill, Muzafargarh while lowest $\left(4266.93 \pm 8.7 \mu \mathrm{g} \mathrm{g}^{-1}\right)$ was observed in Ashraf Sugar Industries Ltd., Bahawalpur compared with all others. Potassium, together with sodium, is essential for the maintenance of normal osmotic pressure within cells, cofactor for numerous enzymes, required for secretion of insulin by the pancreas, for phosphorylation of creatine, for carbohydrate metabolism and for protein synthesis, also. Its loss results in Hypokalaemia, diarrhoea, diabetic acidosis, vomiting, intense and prolonged sweating (COMA, 1991; Fotherby and Potter, 1992; Grimm et al., 1988).

Sodium is also an essential mineral for regulating body fluid balance. Its deficiency is highly unusual, but can lead to low blood pressure, dehydration and muscle cramps (COMA, 1994; Ganry et al., 1993). The highest mean concentration of $\mathrm{Na}\left(8379.17 \pm 108.70 \mu \mathrm{g} \mathrm{g}^{-1}\right)$ was found in Press Mud obtained from Ashraf Sugar Industries Ltd., Bahawalpur while lowest $\left(5885.17 \pm 60.54 \mu \mathrm{g} \mathrm{g}^{-1}\right)$ was observed in The Thal Industries (Unit-I) Corporation Ltd., Layyah.

The mean concentration of $\mathrm{Mg}(5077.83 \pm 64.87 \mu \mathrm{g}$ $\left.\mathrm{g}^{-1}\right)$ remained at highest in Press Mud of Ashraf Sugar Industries Ltd., Bahawalpur while lowest ( $4048.87 \pm 31.66$ $\left.\mu \mathrm{g} \mathrm{g}^{-1}\right)$ was observed at Etihad Sugar Mills Ltd., Rahim Yar Khan from all others. Magnesium is the eighth most abundant element in the earth's crust and is required as a cofactor for many enzyme systems, in protein synthesis, normal functioning of the parathyroid gland for vitamin D metabolism, etc. Its deficiency results in cardiovascular, skeletal, astro-intestinal and central nervous system disorders and to the use of loop diuretics (COMA, 1991; OTC, 2001; Zemel et al., 1990; Altura et al., 1994). The overall scenario showed that all the essential macroelements were potentially present in high concentrations in all the samples collected from five different sites ranging from $\mathrm{Mg}$ having a minimum concentration i.e., $4048.87 \mu \mathrm{g}$ $\mathrm{g}^{-1}$ to Ca having a maximum concentration i.e., $18005.00 \mu \mathrm{g}$ $\mathrm{g}^{-1}$. The mean values of essential macro-elements remained predominantly higher at the Bahawalpur and Layyah regions.

The data obtained for individual elements was also compared statistically by one way ANOVA and the results are depicted in Supplementary Table V indicating F and P values. The results show highly significant $\mathrm{P}$ values $(\mathrm{P}<$ 0.0001 ) among all the elements. The correlation analysis was performed to examine the relationship between all the elements and the results are narrated in Supplementary Table VI. The essential macro-elements are interrelated with each other and with all other elements under consideration as described herewith. The Ca concentration had a strong positive significant relationship $(\mathrm{P}<0.01)$ with $\mathrm{Co}, \mathrm{Fe}$ and $\mathrm{Ba}$ concentration while it had a strong 
negative significant relationship $(\mathrm{P}<0.01)$ with $\mathrm{Na}$, Ni and $\mathrm{Pb}$. It had a positive significant relationship $(\mathrm{P}<0.05)$ with $\mathrm{Cr}$ and $\mathrm{La}$. It had a non-significant relationship $(\mathrm{P}>$ 0.05) with $\mathrm{K}, \mathrm{Mg}, \mathrm{Cu}, \mathrm{Mn}, \mathrm{Zn}, \mathrm{Al}, \mathrm{Cd}, \mathrm{Li}$ and $\mathrm{Sr}$. The $\mathrm{K}$ concentration had a strong positive significant relationship $(\mathrm{P}<0.01)$ with $\mathrm{Cr}, \mathrm{Cd}, \mathrm{La}, \mathrm{Li}$ and $\mathrm{Zn}$ concentration while it had a strong negative significant relationship $(\mathrm{P}<0.01)$ with $\mathrm{Na}$ and $\mathrm{Ni}$. It had a positive significant relationship (P $<0.05)$ with $\mathrm{Fe}$ and $\mathrm{Sr}$. It had a non-significant relationship ( $\mathrm{P}>0.05$ ) with $\mathrm{Mg}, \mathrm{Co}, \mathrm{Cu}, \mathrm{Mn}, \mathrm{Al}, \mathrm{Ba}$ and $\mathrm{Pb}$. The $\mathrm{Na}$ concentration had a strong positive significant relationship $(\mathrm{P}<0.01)$ with $\mathrm{Ni}$ concentration while it had a strong negative significant relationship $(\mathrm{P}<0.01)$ with $\mathrm{Cr}, \mathrm{Fe}$, $\mathrm{Zn}, \mathrm{La}$ and $\mathrm{Li}$. It had a negative significant relationship $(\mathrm{P}<0.05)$ with $\mathrm{Co}, \mathrm{Ba}$ and $\mathrm{Cd}$. It had a non-significant relationship ( $\mathrm{P}>0.05)$ with $\mathrm{Mg}, \mathrm{Cu}, \mathrm{Mn}, \mathrm{Al}, \mathrm{Pb}$ and $\mathrm{Sr}$. The $\mathrm{Mg}$ concentration had a strong positive significant relationship $(\mathrm{P}<0.01)$ with $\mathrm{Fe}, \mathrm{Mn}$ and $\mathrm{Ba}$ concentration. It had a negative significant relationship $(\mathrm{P}<0.05)$ with Ni. It had a non-significant relationship $(\mathrm{P}>0.05)$ with Co, $\mathrm{Cr}, \mathrm{Cu}, \mathrm{Zn}, \mathrm{Al}, \mathrm{Cd}, \mathrm{La}, \mathrm{Li}, \mathrm{Pb}$ and $\mathrm{Sr}$. Our results exhibited that the contents of essential macro-elements present in press mud from all five sites can promise the requirements of an aquaculture fertilizer.

\section{Essential trace elements}

The elements such as $\mathrm{Co}, \mathrm{Cr}, \mathrm{Cu}, \mathrm{Fe}, \mathrm{Mn}, \mathrm{Ni}$ and $\mathrm{Zn}$ are mainly needed in trace amounts for fish and human body functions. Thus, it can be appropriate to observe a comparative account of average/mean concentration with standard error bars of above mentioned elements from Figure 2. The maximum mean concentrations $\left(\mu \mathrm{g} \mathrm{g}^{-1}\right)$ of $\mathrm{Co}, \mathrm{Cr}, \mathrm{Cu}, \mathrm{Fe}, \mathrm{Mn}, \mathrm{Ni}, \mathrm{Zn}$ were observed at $34.12 \pm 0.90$ (The Thal Industries (Unit-I) Corporation Ltd., Layyah), $8.67 \pm 0.26$ (The Thal Industries (Unit-I) Corporation Ltd., Layyah), $49.39 \pm 0.57$ (Fatima Sugar Mill, Muzafargarh), $6671.83 \pm 27.17$ (The Thal Industries (Unit-I) Corporation Ltd., Layyah), $273.33 \pm 6.58$ (Ashraf Sugar Industries Ltd., Bahawalpur), $34.58 \pm 0.50$ (Etihad Sugar Mills Ltd., Rahim Yar Khan) and $122.67 \pm 3.35$ (Fatima Sugar Mill, Muzafargarh) while the minimum mean concentrations $\left(\mu \mathrm{g} \mathrm{g}^{-1}\right)$ were found as $19.66 \pm 0.44$ (Fatima Sugar Mill, Muzafargarh), $0.013 \pm 0.003$ (Etihad Sugar Mills Ltd., Rahim Yar Khan), $12.84 \pm 0.36$ (The Thal Industries (Unit-I) Corporation Ltd., Layyah), $2491.93 \pm 8.32$ (Etihad Sugar Mills Ltd., Rahim Yar Khan), 109.28 \pm 0.47 (Etihad Sugar Mills Ltd., Rahim Yar Khan), $8.10 \pm 0.23$ (The Thal Industries (Unit-I) Corporation Ltd., Layyah) and 85.16 \pm 1.36 (Etihad Sugar Mills Ltd., Rahim Yar Khan).

Cobalt being an integral part of vitamin $B_{12}$ is an essential nutrient having important role in body metabolism (Blakhima, 1970) while Chromium is a trace element having essential role in biological functions i.e., diabetes mellitus control and glucose tolerance (Bratakos et al., 2002) but at the same time is also considered as a pollutant and a toxic metal due to its deployment in manufacturing industries. Copper is another essential micronutrient required for effective homeostatic control, body growth, bone strength, enzymatic functions, defense mechanisms, brain development, iron transport, oxygen transport, cholesterol and glucose metabolism, etc. (Turnlund et al., 1989; Olivares et al., 1998). Its negative balance may result in iron-deficiency/anemia (COMA, 1991; Frykman et al., 1994). Manganese, an essential trace element, is a component of a number of enzymes and many are activated by it. Its deficiency is associated with skeletal malformations, impaired growth and reproductive function (COMA, 1998; Kondakis et al., 1989). Nickel is also an essential element required in trace amounts basically for activation of some enzymatic functions; however, its chronic intake can lead to high risk of lung cancer (EGVM, 2003). Zinc is an essential constituent of more than two hundred metalloenzymes and plays a key role in the synthesis/stabilization of genetic material, synthesis/degradation of carbohydrates, lipids and proteins. Its deficiency results in effects including poor prenatal development, growth/mental retardation, impaired nerve conduction/nerve damage, reproductive failure, dermatitis, hair loss, diarrhea, loss of appetite, loss of taste and smell, anemia, susceptibility to infections, delayed wound healing and macular degeneration (COMA, 1991; Yadrick et al., 1989). The results showed that all the essential trace elements were present in moderate concentrations in all the samples collected from five different sites with the exception of $\mathrm{Fe}$ whose value was relatively high as compared to all other elements. The mean values of the essential trace elements remained predominantly higher at the Layyah and Muzafargarh regions.

The essential trace-elements are interrelated with each other and with all other elements under consideration as described herewith. The Co concentration had a strong positive significant relationship $(\mathrm{P}<0.01)$ with $\mathrm{Ba}$, while it had a strong negative significant relationship $(\mathrm{P}<0.01)$ with $\mathrm{Cu}$. It had a positive significant relationship $(\mathrm{P}<0.05)$ with $\mathrm{Fe}$, while it had a negative significant relationship $(\mathrm{P}<0.05)$ with $\mathrm{Ni}$. It had a non-significant relationship ( $\mathrm{P}>0.05$ ) with $\mathrm{Cr}, \mathrm{Mn}, \mathrm{Zn}, \mathrm{Al}, \mathrm{Cd}, \mathrm{La}, \mathrm{Li}, \mathrm{Pb}$ and $\mathrm{Sr}$. The $\mathrm{Cr}$ concentration had a strong positive significant relationship $(\mathrm{P}<0.01)$ with $\mathrm{Fe}, \mathrm{Zn}, \mathrm{Ba}, \mathrm{Cd}$, $\mathrm{La}$ and $\mathrm{Li}$ concentration, while it had a strong negative significant relationship $(\mathrm{P}<0.01)$ with $\mathrm{Ni}$. It had a non-significant relationship ( $\mathrm{P}>0.05$ ) with $\mathrm{Cu}, \mathrm{Mn} \mathrm{Al}, \mathrm{Pb}$ and $\mathrm{Sr}$. The $\mathrm{Cu}$ concentration had a non-significant relationship $(\mathrm{P}>0.05)$ with $\mathrm{Fe}, \mathrm{Mn}, \mathrm{Ni}, \mathrm{Zn}, \mathrm{Al}, \mathrm{Ba}, \mathrm{Cd}, \mathrm{La}, \mathrm{Li}, \mathrm{Pb}$ and $\mathrm{Sr}$. The Fe concentration had a strong positive significant relationship $(\mathrm{P}<0.01)$ with $\mathrm{Zn}, \mathrm{Ba}$ and $\mathrm{Li}$, while it had a strong 


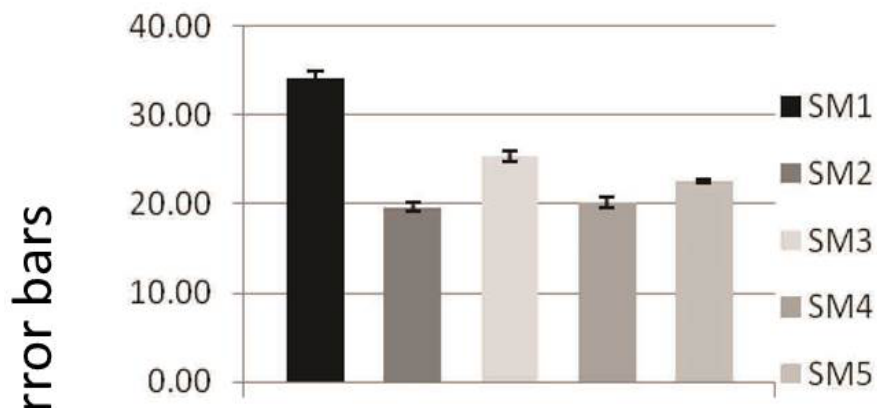

Co
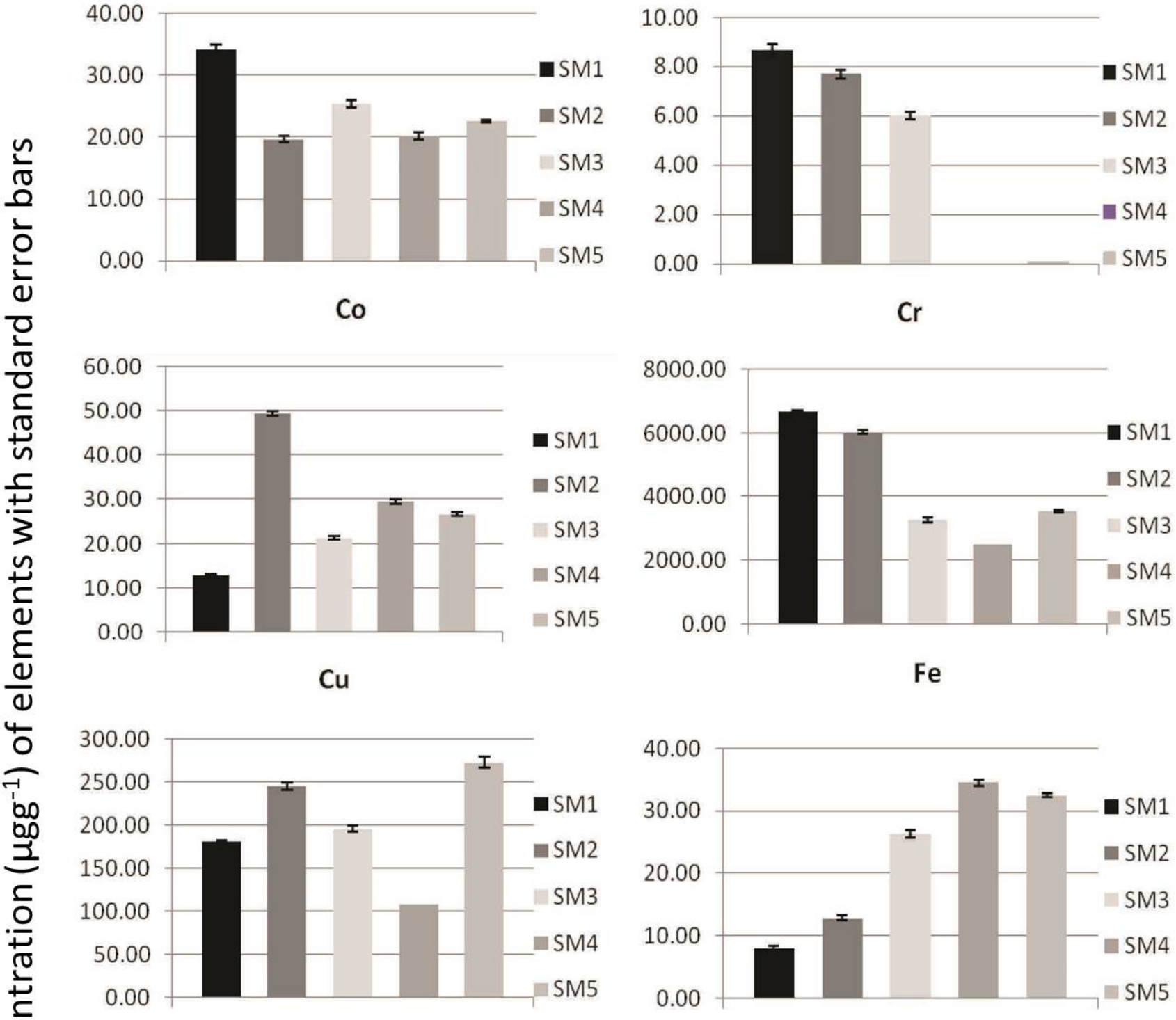

$\mathrm{Mn}$

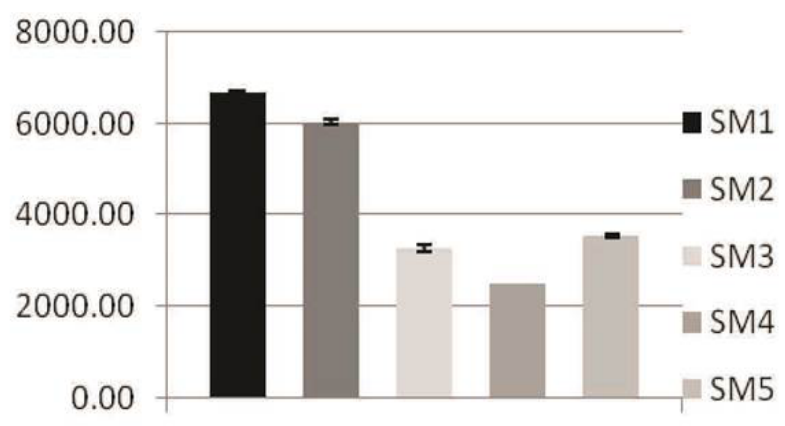

$\mathrm{Fe}$

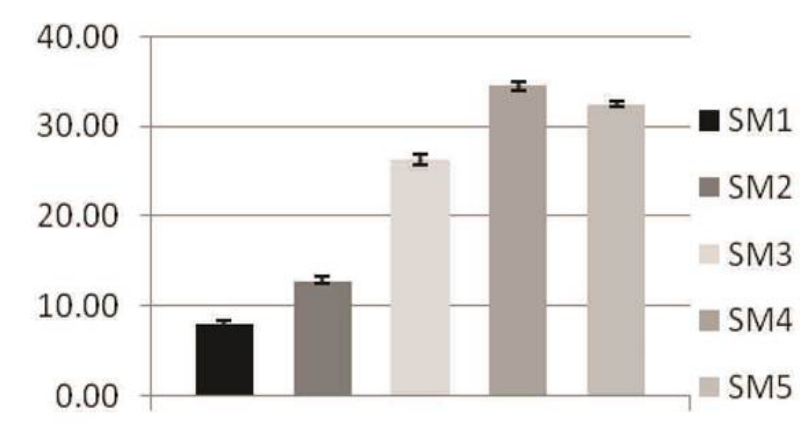

$\mathrm{Ni}$

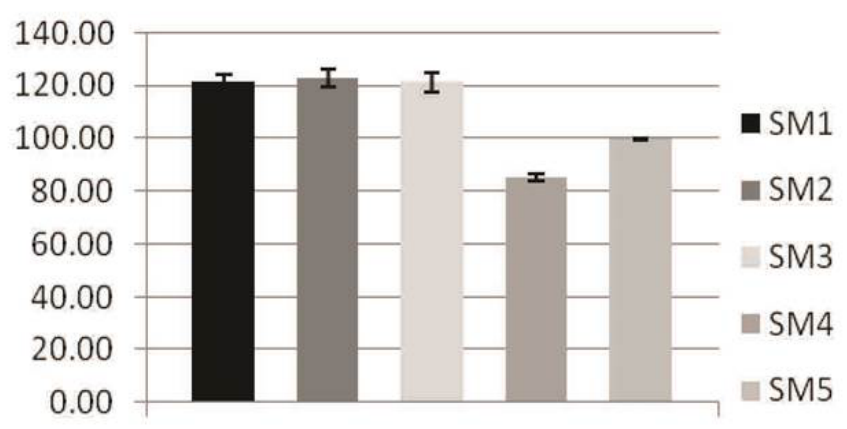

$\mathrm{Zn}$

Fig. 2. Essential mineral trace elements in press mud samples from various Sugar Mills in South Punjab, Pakistan. 

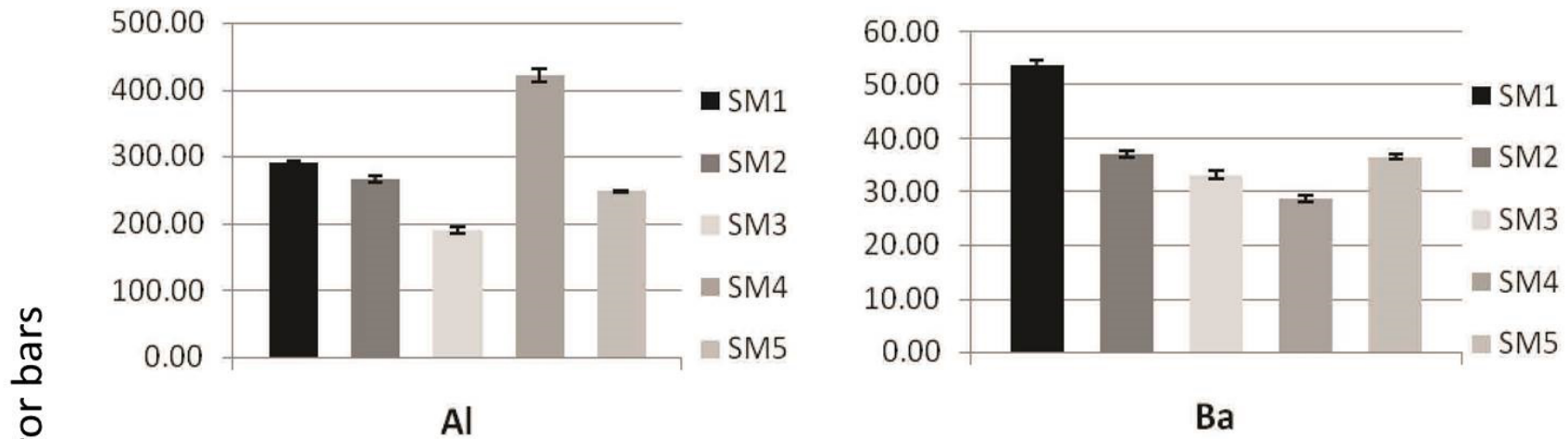

Al

Ba

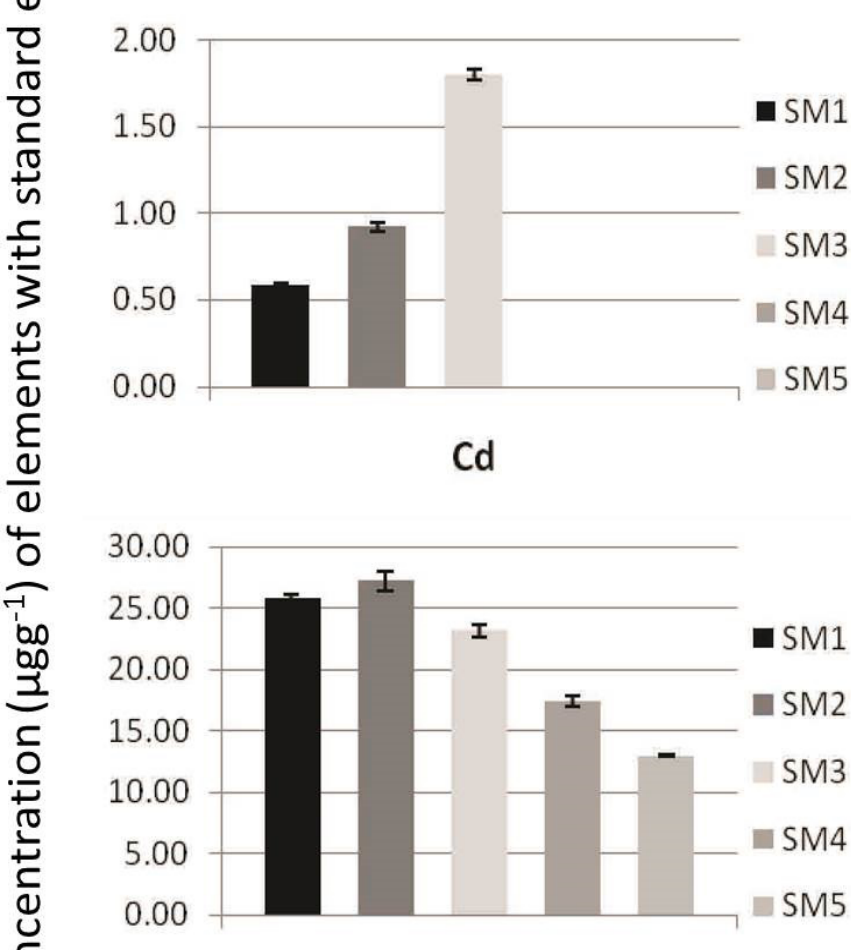

Li

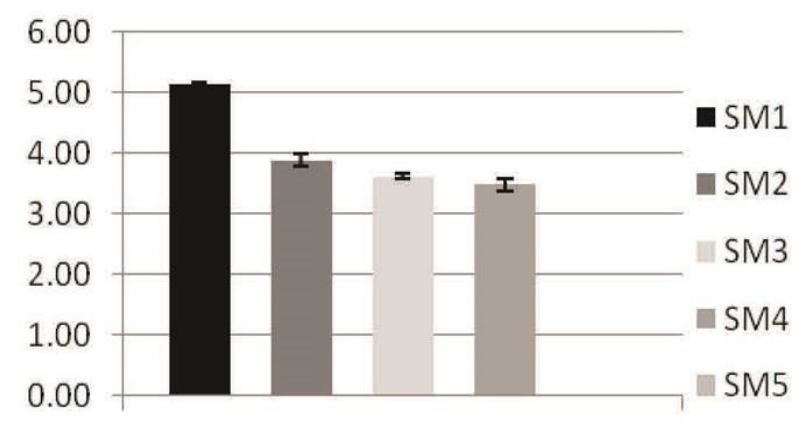

La

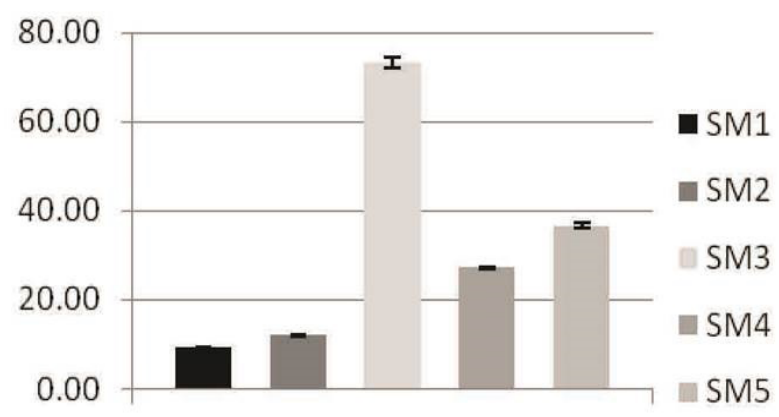

$\mathrm{Pb}$

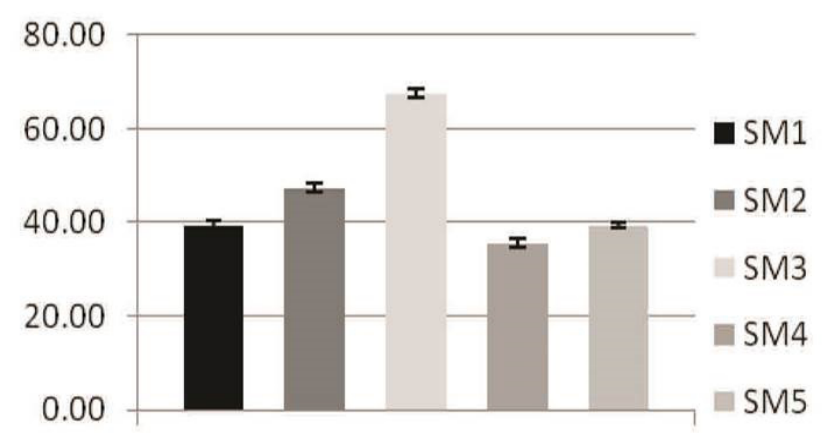

$\mathrm{Sr}$

Fig. 3. Toxic trace elements in press mud samples from various Sugar Mills in South Punjab, Pakistan. 
negative significant relationship $(\mathrm{P}<0.01)$ with $\mathrm{Ni}$ and $\mathrm{Pb}$. It had a non-significant relationship $(\mathrm{P}>0.05)$ with $\mathrm{Mn}$, $\mathrm{Al}, \mathrm{Cd}, \mathrm{La}$ and $\mathrm{Sr}$. Mn concentration had a strong positive significant relationship $(\mathrm{p}<0.01)$ with $\mathrm{Al}$. It had a negative significant relationship $(\mathrm{P}<0.05)$ with $\mathrm{La}$. It had a nonsignificant relationship $(\mathrm{P}>0.05)$ with $\mathrm{Ni}, \mathrm{Zn}, \mathrm{Ba}, \mathrm{Cd}$, $\mathrm{Li}, \mathrm{Pb}$ and $\mathrm{Sr}$. The Ni concentration had a strong negative significant relationship $(\mathrm{P}<0.01)$ with $\mathrm{Zn}, \mathrm{Ba}, \mathrm{La}$ and $\mathrm{Li}$. It had a positive significant relationship $(\mathrm{P}<0.05)$ with $\mathrm{Pb}$. It had a non-significant relationship $(\mathrm{P}>0.05)$ with $\mathrm{Al}$, $\mathrm{Cd}$ and $\mathrm{Sr}$. The results indicated that the essential traceelements available in press mud from all five sites can also fulfill the requirements of an aquaculture fertilizer.

\section{Non-essential/toxic elements}

The elements such as $\mathrm{Al}, \mathrm{Ba}, \mathrm{Cd}, \mathrm{La}, \mathrm{Li}, \mathrm{Pb}$ and $\mathrm{Sr}$ are categorized as non-essential/toxic elements since these have no biological/metabolic functional roles to play in living organisms; rather these are harmful when ingested even in low quantities (Aziz et al., 2011). The comparison of average/mean concentration with standard error bars of these elements present in press mud samples can be effectively perceived from Figure 3 . The maximum mean concentrations $\left(\mu \mathrm{g} \mathrm{g}^{-1}\right)$ of $\mathrm{Al}, \mathrm{Ba}, \mathrm{Cd}, \mathrm{La}, \mathrm{Li}, \mathrm{Pb}, \mathrm{Sr}$ were observed at $421.5833 \pm 11.00$ (Etihad Sugar Mills Ltd., Rahim Yar Khan), $53.9167 \pm 0.83$ (The Thal Industries (Unit-I) Corporation Ltd., Layyah), $1.7967 \pm 0.03$ (Indus Sugar Mills Ltd., Rajanpur), $5.1333 \pm 0.04$ (The Thal Industries (Unit-I) Corporation Ltd., Layyah), 27.2167 \pm 0.81 (Fatima Sugar Mill, Muzafargarh), 73.1667 \pm 1.15 (Indus Sugar Mills Ltd., Rajanpur), $67.4967 \pm 0.99$ (Indus Sugar Mills Ltd., Rajanpur) while the minimum mean concentrations $\left(\mu \mathrm{g} \mathrm{g}^{-1}\right)$ were found as $190.63 \pm 5.07$ (Indus Sugar Mills Ltd., Rajanpur), $28.65 \pm 0.66$ (Etihad Sugar Mills Ltd., Rahim Yar Khan), N.D. (Etihad Sugar Mills Ltd., Rahim Yar Khan and Ashraf Sugar Industries Ltd., Bahawalpur), N.D. (Ashraf Sugar Industries Ltd., Bahawalpur), $12.97 \pm 0.09$ (Ashraf Sugar Industries Ltd., Bahawalpur), $9.20 \pm 0.22$ (The Thal Industries (Unit-I) Corporation Ltd., Layyah) and $35.60 \pm 0.98$ (Etihad Sugar Mills Ltd., Rahim Yar Khan). The results indicated that all the non-essential/toxic elements were either not detected in some of the samples and even if present were in very low concentrations. This was a very positive sign so that it can be used as fertilizer without fear of toxicity and contamination of the aquatic media of Aquaculture systems. The mean values of non-essential/toxic elements remained predominantly higher at the Rajanpur and Layyah regions.

The non-essential toxic elements are interrelated with each other and with all other elements under consideration as described herewith. The Al concentration had a strong negative significant relationship $(\mathrm{P}<0.01)$ with $\mathrm{Cd}$ and $\mathrm{Sr}$, while had a non-significant relationship $(\mathrm{P}>0.05)$ with $\mathrm{Ba}$ $\mathrm{La}, \mathrm{Li}$ and $\mathrm{Pb}$. The $\mathrm{Ba}$ concentration had a non-significant relationship $(\mathrm{P}>0.05)$ with $\mathrm{Cd}, \mathrm{La}, \mathrm{Li}, \mathrm{Pb}$ and $\mathrm{Sr}$. $\mathrm{Cd}$ concentration had a strong positive significant relationship $(\mathrm{p}<0.01)$ with $\mathrm{Sr}$ concentration and a positive significant relationship $(\mathrm{P}<0.05)$ with $\mathrm{Li}$ and $\mathrm{Pb}$, while had a non-significant relationship $(\mathrm{P}>0.05)$ with $\mathrm{La}$. The La concentration had a strong positive significant relationship $(\mathrm{P}<0.01)$ with $\mathrm{Li}$ and a non-significant relationship $(\mathrm{P}$ $>0.05)$ with $\mathrm{Pb}$ and $\mathrm{Sr}$. The Li concentration had a nonsignificant relationship $(\mathrm{P}>0.05)$ with $\mathrm{Pb}$ and $\mathrm{Sr}$. The $\mathrm{Pb}$ concentration had a strong positive significant relationship $(\mathrm{P}<0.01)$ with $\mathrm{Sr}$ concentration. The overall results demonstrated that the total non-essential elements present in press mud from all five sites were in low quantities making it possible to use it as an aquaculture fertilizer.

\section{DISCUSSION}

Our research results are mostly in agreement with the previous published studies from various regions of the world as described in Table I. Memon et al. (2012) tested the potential of three agricultural waste composts in pot experiment growing maize and recommended that press mud could be recycled thus sustaining the balance between economic development and environmental protection. In another experiment by Cifuentes et al. (2013), press mud composite along with a mixture of bagasse substituted with waste sugarcane was used as a fertilizer on large scale in the greenhouse environment resulting in the maximum tomato plant height and weight. Moreover, Maheera et al. (2013) assessed that the soil amended with press mud attained the ability of reducing the concentration of heavy metals leachability and its application as a landfill soil cover can aid in landfill management to minimize heavy metals contamination and operating costs. Paksoy et al. (2018) evaluated the essential and heavy metals in milks of dairy donkeys, goats and sheep in Turkey in the same manner as under this research. Our study is also supported by Kumar et al. (2011) who analyzed press mud compost for zinc, manganese, iron and aluminum and concluded it to be a good source of soil elements and organic matter for application to the agricultural land. Furthermore, Rouf et al. (2010) collected press mud from sugar mills situated in Punjab, India and analyzed macronutrients and micronutrients on \% dry basis and reported that the digested slurry of press mud could be used as a fertilizer since it was rich in plant nutrients. Ramesh et al. (2004) emphasized and proved that a judicious combination of inorganic, organic and biofertilizers is a potential tool for sustaining the cane productivity as well as' soil fertility in sugarcane and sugarcane based cropping systems. 


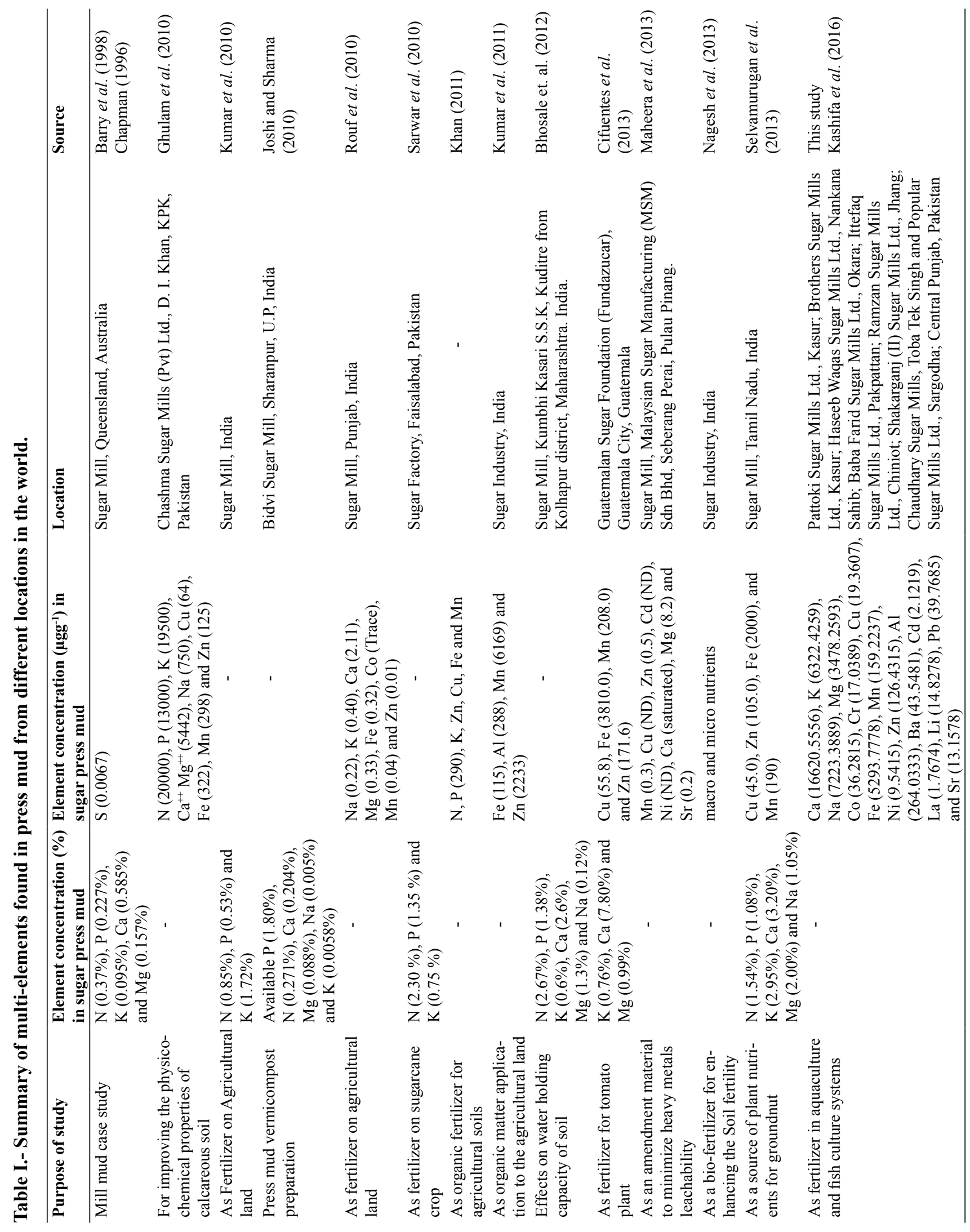


They applied farmyard manure, cane trash, press mud, vermicompost and biocompost in combination with recommended inorganic fertilizers and attained recorded increased cane yield over inorganic fertilizer alone, besides improving the soil fertility and economizing the cane production. Results of Nagesh et al. (2013) are also in agreement of our research since they proved that sugar press mud (SPM) is a valuable bio-fertilizer and useful to increase the macro and micro nutrient of soil thus enhancing the soil fertility. Zafar et al. (2013) determined the effect of different doses of press mud on $\mathrm{Cu}$ and $\mathrm{Ni}$ concentrations of oat fodder (Avena sativa L.) in Sargodha, Pakistan. They revealed that feeding ruminants with this fodder would be safe with no potential threat of heavy metals concentration which did not rise above the suggested reference standards. They concluded that press mud fertilizer did not show heavy metal poisonous squander; additionally proved to be a first rater source of soil elements and organic stuff to the agricultural land. Ghulam et al. (2010) assessed the application of press mud (a waste by-product from sugar factories) as organic amendment @15 to $20 \mathrm{t} \mathrm{ha}^{-1}$ as the most suitable dose for improving the physico-chemical properties of calcareous soil. Khan (2011) also suggested that SPM can be considered as one of the good options to use this organic waste/bio-solid as organic fertilizer for better crop and fodder yields in an environment friendly manner and its application to agricultural soils would be sustainable and economical due to nutrient cycling and disposal of the waste on basis of his research on this sugar industry by-product.

On the basis of our research, also supported by the previous literature explained above, Press Mud can be considered as a beneficial source of essential metals allowing leaching of these into the water body of the ponds; making the medium well fertile and hence making it possible for this by-product of sugar industry to be used as an aqua-fertilizer in fish ponds. However, a further research in this context will also be conducted for evaluation and requirement of the exact amount of sugar press mud application as an aquaculture fertilizer for fish growth.

\section{CONCLUSION}

This research provided detailed information on the presence of elements and their correlation being significantly different from each other $(\mathrm{P}<0.05, \mathrm{P}<$ $0.01, \mathrm{P}<0.001, \mathrm{P}<0.0001)$. Owing to the presence of sufficient amounts of essential-macro and essentialtrace elements in press mud, we recommend its future utilization as an aquaculture and agriculture fertilizer for economical stabilization using the concept of $3 \mathrm{R}$ formula for waste management i.e. reduce, recycle and reuse. It may be concluded that the sugar press mud, a sugar mill by-product can be considered as one of the good options for using this organic and waste bio-solid as an organic, highly valuable, futuristic naturally fortified fertilizer in intensive/semi- intensive aquaculture/fish ponds for better fish growth, yields and production in an environment friendly manner.

\section{Supplementary material}

There is supplementary material associated with this article. Access the material online at: http://dx.doi. org/10.17582/journal.pjz/2018.50.4.1329.1340

\section{Statement of conflict of interest}

Authors have declared no conflict of interest.

\section{REFERENCES}

Altura, B.T., Wilimzig , C., Trnovec, T., Nyulassy, S. and Altura, B.M., 1994. Comparative effects of magnesium enriched diets and different orally administered magnesium oxide preparations on ionized $\mathrm{Mg}, \mathrm{Mg}$ metabolism and electrolytes in serum of human volunteers. J. Am. Coll. Nutr., 13: 447-454. https://doi.org/10.1080/07315724.1994.1 0718433

Aziz, A.F., Saei-Dehkordi, S., Nematollahi, A. and Jafari, T., 2011. Comparative study of heavy metal and trace element accumulation in edible tissues of farmed and wild rainbow trout (Oncorhynchus mykiss) using ICP-OES technique. Microchem. J., 98: 275-279. https://doi.org/10.1016/j. microc. 2011.02 .007

Blakhima, R.J., 1970. Trace element metabolism in animals, Vol 1. Livingstone, Edinburgh.

Bratakos, M., Lazos, E.S. and Bratakos, S.M., 2002. Chromium content of selected Greek foods. Sci. Total Environ., 290: 47-58. https://doi.org/10.1016/ S0048-9697(01)01057-9

Bucher, H.C., Guyatt, G.H., Cook, R.J., Hatala, R., Cook, D.J., Lang, J.D. and Hunt, D., 1996. Effect of calcium supplementation on pregnancy-induced hypertension and pre-eclampsia. J. Am. med. Assoc., 275: 1113-1117. https://doi.org/10.1001/ jama.275.14.1113

Cifuentes, R., de Leo'n, R., Porres, C. and Rolz, C., 2013. Windrow composting of waste sugar cane and press mud mixtures. Sugar Tech, 15: 406-411. https://doi.org/10.1007/s12355-013-0217-x

COMA, 1991. Dietary reference values for food energy and nutrients for the United Kingdom. 
Report of the Panel on Dietary Reference Values, Committee on Medical Aspects of Food and Nutrition Policy. HMSO, London. https://doi. org/10.1111/j.1753-4887.1992.tb01280.x

COMA, 1994. Nutritional aspects of cardiovascular disease. Report of the Cardiovascular Review Group, Committee on Medical Aspects of Food and Nutrition Policy. HMSO, London. Rep. Hlth. Soc. Subj., 46: 1-186.

COMA, 1998. Nutrition and bone health with particular reference to calcium and vitamin $D$. Report of the Subgroup on Bone Health, Working Group on the Nutritional Status of the Population, Committee on Medical Aspects of Food and Nutrition Policy. The Stationery Office, London. http://webarchive. nationalarchives.gov.uk/+/www.dh.gov.uk/ en/Publicationsandstatistics/Publications/ PublicationsPolicyAndGuidance/DH_4005936.

EGVM, 2003. Risk assessment: Nickel. Expert Group on Vitamins and Minerals. http://archive.food.gov. uk/dept_health/pdf/evmpdf/evm9924.pdf.

Fotherby, M.D. and Potter, J.F., 1992. Potassium supplementation reduces clinic and ambulatory blood pressure in elderly hypertensive patients. J. Hyperten., 10: 1403-1408. https://doi. org/10.1097/00004872-199211000-00013

Frykman, E., Bystrom, M., Jansson, U., Edberg, A. and Hansen, T., 1994. Side effects of iron supplements in blood donors; superior tolerance of heme iron. $J$. Lab. Clin. Med., 123: 561-564.

Ganry, O., Boudet, J., Wargon, C., Hornych, A. and Meyer, P.J., 1993. Effect of sodium bicarbonate and sodium chloride on arterial blood pressure, plasma renin activity and urinary prostaglandins in healthy volunteers. J. Hyperten., 11: S202-S203. https:// doi.org/10.1097/00004872-199312050-00080

Ghulam, S., Khan, M.J., Usman, K. and Rehman, H., 2010. Impact of press mud as organic amendment on physico-chemical characteristics of calcareous soil. Sarhad J. Agric., 26: 565-570.

Grimm, R.H., Kofron, P.M., Neaton, J.D., Svendsen, K.H., Elmer, P.J., Holland, L., Witte, L.J., Clearman, D. and Prineas, R.J., 1988. Effect of potassium supplementation combined with dietary sodium reduction on blood pressure in men taking antihypertensive medication. J. Hyperten., 6: S591-S593. https://doi.org/10.1097/00004872198812040-00185

Kale, S.P. and Shinde, B.N., 1986. Use of press mud cake for crop production. Bharatiya Sugar, 11: 6368.

Khan, M.J., 2011. Impact of selected doses of organic wastes on physico-chemical characteristics of the soil and yield of wheat. $2^{\text {nd }}$ International Conference on Environmental Engineering and Applications. IACSIT Press, Singapore, pp. 271-275. http:// www.ipcbee.com/vol17/50-U00037.pdf.

Kondakis, X.G., Makris, N., Leotsinidis, M., Prinou, M. and Papapetropoulos, T., 1989. Possible health effects of high manganese concentration in drinking water. Arch. environ. Hlth., 44: 175-178.

Kumar, B., Kumar, S., Prakash, D., Singh, S.K., Mishra, M., Jain, P.K., Lal, R.B., Sharma, C.S. and Mukherjee, D.P., 2011. A study on sugar mill pressmud compost for some heavy metal content and their bio-availability. Asian J. Pl. Sci. Res., 1: 115-122.

Maheera, M., Syahidah, A.A., Harlina, A., Norli, I. and Morad, N., 2013. Preliminary study of composite pressmud and laterite soil in minimizing leachability of heavy metals. Int. J. Chem. environ. Engin., 4: 319-322.

Memon, M., Memon, K.S., Mirani, S. and Jamro, G.M., 2012. Comparative evaluation of organic wastes for improving maize growth and NPK content. Afri. J. Biotechnol., 11: 9343-9349. https://doi. org/10.5897/AJB12.004

Nagesh, N.P., Sumit, J., Sachin, S.G. and Abhijeetkumar, B.S., 2013. Isolation and enrichment of sugar press mud (SPM) adapted microorganism for production of biofertilizer by using sugar press mud. Int. J. Adv. Biotechnol. Res., 4: 96-104.

Naseem, A., 2009. Biocompositing of sugar factory press mud as a CDM project. Proceedings of Workshops on Engineering and Processing in the Sugar Industry Pakistan Society.

AOAC, 2012. Official methods of analysis, $19^{\text {th }}$ Ed., AOAC International, Gaithersburg, MD, USA; Metals and other elements, AOAC SMPR, Vol 1,Ch 9; AOAC Official methods of analysis 990.08, pp. 46-50.

Olivares, M., Pizarro, F., Speisky, H., Lonnerdal, B. and Uauy, R., 1998. Copper in infant nutrition: safety of World Health Organization provisional guideline value for copper content of drinking water. J. Ped. Gastroenterol. Nutri., 26: 251-257. https://doi. org/10.1097/00005176-199803000-00003

OTC, 2001. OTC directory 2001-2002. Proprietary Association, Great Britain.

Paksoy, N., Dinç, H. and Altun, S.K., 2018. Evaluation of levels of essential elements and heavy metals in milks of dairy donkeys, goats and sheep in Turkey, Pakistan J. Zool., 50: 1097-1105. http://dx.doi. org/10.17582/journal.pjz/2018.50.3.1097.1105 
PSMA, 2014. Pakistan Sugar Mills Association, annual report 2014. 49 $9^{\text {th }}$ Annual General Meeting, Annual Review September 2014.

Partha, N. and Krishnan, M.R.V., 2000. Press mud for chemicals/fine chemicals. Kisan World, 27: 11-35.

Partha, N. and Sivasubramanian, V., 2006. Recovery of chemicals from press mud-A sugar industry waste. Indian Chem. Engin. Sec. A, 48: 3.

Qureshi, M.E., Wegener, M.K. and Mallawaarachchi, T., 2001. The economics of sugar mill waste management in the Australian sugar industry: Mill mud case study. 45 $5^{\text {th }}$ Annual Conference of the Australian Agricultural and Resource Economics Society, Adelaide, South Australia.

Ramesh, T., Chinnusamy, C. and Jayanthi, C., 2004. Bio organic nutrient management in sugarcane production - A review. Agric. Rev., 25: 201-210.

Rashi, S., Chandra, R., Kumar, N. and Tyagi, A.K., 2005. Utilization of composted sugar industry waste (press mud) to improve properties of sodic soil for rice cultivation. J. environ. Sci. Engin., 47: 212-217.

Rouf, M.A., Bajpai, P.K. and Jotshi, C.K., 2010. Optimization of biogas generation from press mud in batch reactor. Bangladesh J. scient. indust. Res., 45: 371-376.

Saravane, R., Sivasankaran, M.A. and Sundararaman, S., 2005. Anaerobic pretreatment and increased sold destruction of organic municipal solid waste and secondary sewage sludge for reuse and recovery. Department of Civil Engineering, Pondicherry
Engineering College, Pondicherry and Department of Environmental Engineering, PES College of Engineering, Karnataka.

Solaimalal, A., Baskar, M., Ramesh, P.T. and Ravisankar, N., 2001. Utilization of press mud as soil amendment and organic manure- A review. Agric. Rev., 22: 25-32.

Steel, R.G.D., Torrie, J.H. and Dinkkey, D.A., 1996. Principals and procedures of statistics, $\left(2^{\text {nd }} \mathrm{ed}.\right)$. Mc Graw-Hill Publishers.

Turnlund, J.R., Keys, W.R., Anderson, H.L. and Acord, L.L., 1989. Copper absorption, excretion, and retention in young men at three levels of by use of the stable isotope $65 \mathrm{Cu}$. Am. J. clin. Nutr., 49: 870878. https://doi.org/10.1093/ajcn/49.5.870

Yadrick, M.K., Kenney, M.A. and Winterfeldt, E.A., 1989. Iron, copper and zinc status: response to supplementation with zinc or zinc and iron in adult females. Am. J. clin. Nutr., 49: 145-150. https://doi. org/10.1093/ajen/49.1.145

Zafar, I.K., Kashaf, S., Ahmad, K., Shaheen, M., Younis, S. and Arshad, F., 2013. Impact of use of press mud as fertilizer on the concentration of copper and nickel in the soil and livestock oat fodder. Pakistan J. Zool., 45: 1221-1227.

Zemel, P.C., Zemel, M.B., Urberg, M., Douglas, F.L., Geiser, R. and Sowers, J.R., 1990. Metabolic and hemodynamic effects of magnesium supplementation in patients with essential hypertension. Am. J. Nutr, 51: 665-669. https://doi. org/10.1093/ajen/51.4.665 